DOI

\title{
ВПЛИВ ВИКЛЮЧЕННЯ БЕТА -АДРЕНОРЕЦЕПТОРІВ АСОЦІАТИВНОЇ КОРИ ДОРОСЛИХ ЩУРІВ НА АВТОНОМНУ РЕГУЛЯЦІЮ СЕРЦЕВОГО РИТМУ ЗА УМОВ ЗНИЖЕНОГО АТМОСФЕРНОГО ТИСКУ
}

ОН. М. Волкова

\section{ДВНЗ «Тернопільський державний медичний університет імені І. Я. Горбачевського МОз України»}

РЕЗЮМЕ. У літературі повідомляється про можливість блокування бета-адренергічних рецепторів препаратом селективної дії небівололом [3]. Але немає даних про ефекти блокування бета, -адренорецепторів у асоціативних полях кори головного мозку на автономну регуляцію серцевого ритму. Водночас $\epsilon$ можливість дозованого моделювання гіпобаричних і гіпоксичних умов в експерименті. Метою експерименту було виявити функціональні наслідкивиключення бета,-адренорецепторів васоціативній корі дорослихщурів заумов зниженого атмосферного тиску. В експерименті виключення бета, -адренорецепторів в асоціативній корі дорослих щурів за

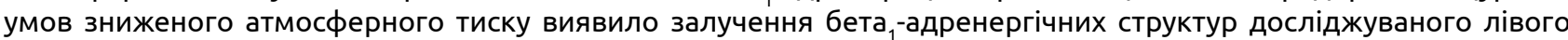
асоціативного кіркового поля до нейронних ланцюгів, які створювали парасимпатичний вплив на серцевий ритм, що відрізнялося від ефекту небівололу при нормальному атмосферному тиску.

КЛЮчОВІ СЛОВА: бета,-адренергічні рецептори, автономна регуляція серцевого ритму, знижений атмосферний тиск.

Вступ. Дослідження участі речовин медіаторної дії у формуванні адаптації регуляторних систем мозку до гіпоксичного впливу $\epsilon$ актуальною проблемою, оскільки відомо про дезадаптивні зміни регуляції регіонарного кровообігу у метеочутливих осіб при III типі погоди, який характеризується зниженням всмісту кисню в повітрі і зниженням атмосферного тиску [1]. Внаслідок цих змін у гомеостатичних механізмах мозку в метеочутливих осіб відбувається погіршення розумової працездатності та прискорюється формування психосоматичних розладів [2].

В літературі повідомляється про можливість блокування бета,-адренергічних рецепторів препаратом селективної дії небівололом [3]. Але немає даних про ефекти блокування бета адренорецепторів у асоціативних полях кори головного мозку на автономну регуляцію серцевого ритму. Водночас $\epsilon$ можливість дозованого моделювання гіпобаричних і гіпоксичних умов в експерименті.

Мета дослідження. Метою експерименту було виявити функціональні наслідки виключення бета ${ }_{1}$-адренорецепторів в асоціативній корі дорослих щурів за умов зниженого атмосферного тиску.

Матеріал і методи дослідження. Експериментальні дослідження проведені на нелінійних молодих щурах обох статей віком 6-8 місяців масою 175-230 г. Усі експерименти проведені при метеоситуації I типу, що виключало несприятливий вплив природних змін атмосферних умов. В експериментальній групі (по 10 тварин) реєстрували кардіоінтервалограму до гіпоксії, після гіпоксичного впливу, після трепанації че- репа (були окремі групи з правобічною і з лівобічною трепанацією в проекції кіркової ділянки Oc2L), після введення бета,-адреноблокатора небівололу $(0,5 \mathrm{Mr} / \mathrm{kr})$ через трепанаційний отвір на поверхню кори великих півкуль, із подальшим автоматичним аналізом даних на персональному компьютері. В контрольній групі (по 10 тварин) здійснили аналогічний порядок експерименту, за виключенням гіпоксичного впливу. При аналізі результатів кардіоінтервалографії обраховували середнє значення, стандартне відхилення, варіаційний розкид $(\Delta \mathrm{X})$, моду (Мо), амплітуду моди (АМо), індекс напруження (IH), вегетативний показник ритму (ВПР) $[4,5]$. Вплив гіпоксичної атмосфери створювали за допомогою зниження тиску на 50,76 гПа (0,05 атм) в апараті Комовського й утримування занаркотизованого щура під скляним куполом протягом 1 год.

Усіх тварин утримували на стандартному раціоні віварію. Дослідження виконували відповідно до «Загальних етичних принципів експериментів на тваринах», ухвалених Першим національним конгресом з біоетики (Київ, 2001) та узгоджених з положеннями «Європейської конвенції щодо захисту хребетних тварин, які використовуються для експериментальних і інших наукових цілей» (Страсбург, 1986). Комісією з біоетики ДВНЗ «Тернопільський державний медичний університет імені І. Я. Горбачевського МОЗ України» порушень морально-етичних норм при проведенні науководослідної роботи не виявлено.

Результати й обговорення. У дорослих тварин контрольної групи після введення небівололу в трепанаційний отвір справа спостерігали деяке посилення парасимпатичних впливів на серцевий 
Огляди літератури, оригінальні дослідження, погляд на проблему

ритм (табл. 1). Зокрема зростала варіабельність серцевого ритму, знизився ВПР на $19 \%$. ІН суттєво не відрізнявся від інтактних тварин в контрольній групі, отже, при нормальному атмосферному тиску бета,-адренергічні структури були залучені до підтримання достатньої активності центрального контуру регуляції серцевого ритму, який функціонально пов'язаний із симпатичними впливами на серцевий ритм. Подібна динаміка показників спостерігалася у дорослих щурів контрольної гру- пи із лівобічним введенням небівололу, зокрема ВПР знизився на $25 \%$.

Гіпоксичний вплив призводив до активації парасимпатичних впливів на серцевий ритм. Порівняно зі станом після гіпоксії, введення небівололу справа викликало у дорослих тварин експериментальної групи зниження IH на $45 \%$, зниження ВПР на $45 \%$. Отже, спостерігали значно більший ступінь активації парасимпатичних механізмів регуляції, ніж у контрольній групі після введення небівололу справа.

Таблиця 1. Стан автономної регуляції у дорослих щурів з трепанацією справа

\begin{tabular}{|c|c|c|c|c|}
\hline \multirow{2}{*}{\multicolumn{2}{|c|}{ Показник }} & \multicolumn{3}{|c|}{ Група тварин } \\
\hline & & \multirow{2}{*}{$\frac{\text { інтактні }}{0,138 \pm 0,001}$} & \multirow{2}{*}{$\begin{array}{c}\text { після гіпоксії } \\
-\end{array}$} & \multirow{2}{*}{$\begin{array}{c}\text { після введення небівололу } \\
0,138 \pm 0,001\end{array}$} \\
\hline$M C$ & $\mathrm{~K}$ & & & \\
\hline $\mathrm{N}, \mathrm{C}$ & $\mathrm{e}$ & $0,179 \pm 0,001$ & $0,268 \pm 0,001$ & 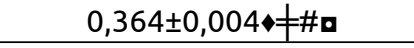 \\
\hline \multirow{2}{*}{$\Delta \mathrm{X}, \mathrm{c}$} & $\mathrm{K}$ & $0,005 \pm 0,001$ & - & $0,006 \pm 0,001$ \\
\hline & $\mathrm{e}$ & $0,004 \pm 0,001$ & $0,021 \pm 0,008$ & $0,029 \pm 0,016 \# \mathbf{q}$ \\
\hline \multirow{2}{*}{ Mo, c } & $\mathrm{K}$ & $0,137 \pm 0,001$ & - & $0,136 \pm 0,001$ \\
\hline & $\mathrm{e}$ & $0,179 \pm 0,001$ & $0,267 \pm 0,001$ & $0,363 \pm 0,004$ •\#口 \\
\hline \multirow{2}{*}{ AMo, \% } & K & $33,33 \pm 1,33$ & - & $34,0 \pm 1,229$ \\
\hline & e & $49,8 \pm 2,691$ & $20,0 \pm 0,596$ & $20,5 \pm 0,596 » \#$ \\
\hline \multirow{2}{*}{ ІН, ум. од. } & $\mathrm{K}$ & $24345,417 \pm 45,909$ & - & $20186,916 \pm 67,031$ \\
\hline & e & $35554,118 \pm 83,102$ & $3459,971 \pm 70,375$ & $1888,172 \pm 4,434$ •\#\#ロ \\
\hline \multirow{2}{*}{ ВПР, ум. од. } & $\mathrm{K}$ & $1470,860 \pm 45,708$ & - & $1186,898 \pm 22,785$ \\
\hline & $\mathrm{e}$ & $1392,775 \pm 8,565$ & $348,759 \pm 6,937$ & $190,751 \pm 20,878$ \\
\hline \multicolumn{5}{|c|}{ 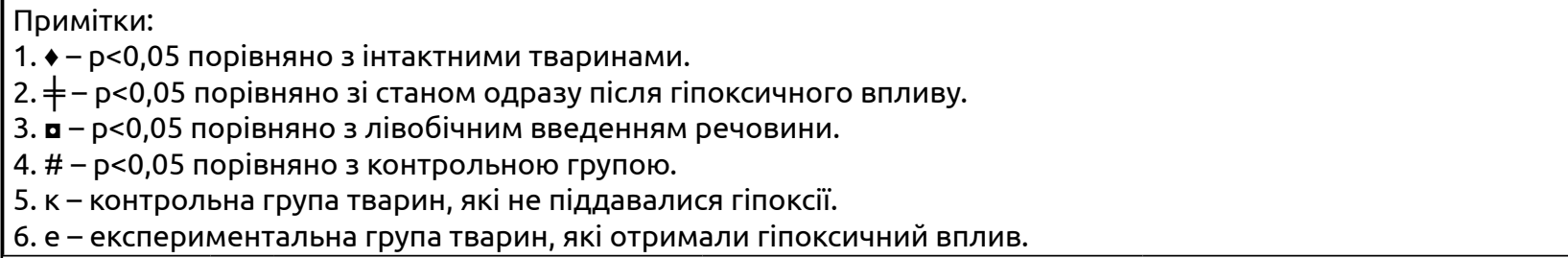 } \\
\hline
\end{tabular}

Небіволол викликав при лівобічному введенні у дорослих тварин експериментальної групи збільшення активації симпатичних впливів, порівняно зі станом після гіпоксичного впливу (табл. 2), зокрема ІН збільшився на $34 \%$, ВПР збільшився на $15 \%$. Таким чином, після помірного гіпоксичного впливу бета,-адренергічні структури досліджуваного лівого асоціативного кіркового поля уже були задіяні до нейронних ланцюгів, які створювали парасимпатичний вплив на серцевий ритм.

В літературних джерелах повідомляється, що небіволол підвищує реакцію судин на ацетилхолін, опосередковану монооксидом азоту і завдяки L-енантіоміру чинить слабку судинорозширювальну дію внаслідок метаболічної взаємодії з L-аргініном або оксидом азоту $[6,7,8]$. За нашими даними, $\mathrm{M}_{1}$-холінорецепторні структури досліджуваного правого і лівого асоціативних кіркових полів залучені до нейронних ланцюгів, які чинять парасимпатичний вплив на серцевий ритм, і тому їх активація може пояснювати результати експе- риментальної групи щурів з правобічним введенням небівололу.

Злітерутуривідомо, щозавдякиD-енантіоміру небіволол $\epsilon$ конкурентним і селективним блокатором бета Тому, на нашу думку, збільшення IH і ВПР після введення небівололу зліва в експериментальній групі дорослих щурів можна пояснити селективним і конкурентним блокуванням бета адренергічних рецепторів.

За даними літератури, реакції негайної адаптації організму, спрямовані на підтримання кисневого гомеостазу [9], ведуть до змін рецепторних функцій мембранних білків і синаптичної передачі збудження. У дорослих тварин після перебування в гіпоксичному середовищі виявлене нами посилення парасимпатичних енергозберігаючих механізмів регуляції серцевого ритму обмежує функціональні резерви нервової системи і опосередковано зменшує кровопостачання асоціативної кори. За нашими попередніми даними, у 
Огляди літератури, оригінальні дослідження, погляд на проблему

Таблиця 2. Стан автономної регуляції у дорослих щурів з трепанацією зліва

\begin{tabular}{|c|c|c|c|c|}
\hline \multirow{2}{*}{\multicolumn{2}{|c|}{ Показник }} & \multicolumn{3}{|c|}{ Група тварин } \\
\hline & & \multirow{2}{*}{$\frac{\text { інтактні }}{0,145 \pm 0,001}$} & \multirow{2}{*}{$\frac{\text { після гіпоксії }}{-}$} & \multirow{2}{*}{$\begin{array}{c}\text { після введення небівололу } \\
0,155 \pm 0,001\end{array}$} \\
\hline & $\mathrm{K}$ & & & \\
\hline $\mathrm{M}, \mathrm{C}$ & $\mathrm{e}$ & $0,179 \pm 0,001$ & $0,235 \pm 0,002$ & $0,202 \pm 0,001 \neq \#$ \\
\hline \multirow{2}{*}{$\Delta \mathrm{X}, \mathrm{c}$} & $\mathrm{K}$ & $0,004 \pm 0,001$ & - & $0,004 \pm 0,001$ \\
\hline & $\mathrm{e}$ & $0,027 \pm 0,11$ & $0,012 \pm 0,001$ & $0,043 \pm 0,021=\#$ \\
\hline \multirow{2}{*}{ Mo, c } & $\mathrm{K}$ & $0,144 \pm 0,001$ & - & $0,154 \pm 0,001$ \\
\hline & e & $0,177 \pm 0,001$ & $0,234 \pm 0,002$ & $0,202 \pm 0,001=$ \\
\hline \multirow{2}{*}{ AMo, \% } & $\mathrm{K}$ & $40,600 \pm 2,281$ & - & $39,200 \pm 2,122$ \\
\hline & $\mathrm{e}$ & $26,0 \pm 2,516$ & $16,400 \pm 1,002$ & $21,0 \pm 1,211=$ \\
\hline \multirow{2}{*}{ ІН, ум. од. } & $\mathrm{K}$ & $33010,420 \pm 40,347$ & - & $30454,902 \pm 56,199$ \\
\hline & e & $7750,371 \pm 6,875$ & $2945,120 \pm 5,835$ & $4440,143 \pm 99,521 \neq$ \\
\hline \multirow{2}{*}{ ВПР, ум. од. } & $\mathrm{K}$ & $1629,643 \pm 56,086$ & - & $1554,081 \pm 41,946$ \\
\hline & $\mathrm{e}$ & $557,745 \pm 9,882$ & $354,836 \pm 18,320$ & $416,577 \pm 97,131 \diamond \neq \#$ \\
\hline \multicolumn{5}{|c|}{$\begin{array}{l}\text { Примітки: } \\
\text { 1. - р<0,05 порівняно з інтактними тваринами. } \\
\text { 2. } \neq- \text { - }<0,05 \text { порівняно зі станом одразу після гіпоксичного впливу. } \\
\text { 3. \# - р<0,05 порівняно з контрольною групою. } \\
\text { 4. к- контрольна група тварин, які не піддавалися гіпоксії. } \\
\text { 5. е- експериментальна група тварин, які отримали гіпоксичний вплив. }\end{array}$} \\
\hline
\end{tabular}

метеочутливих людей при метеоситуації III типу гіпоксичний вплив призводить до активації парасимпатичних енергозберігаючих впливів [10], що подібно до регуляторних реакцій у щурів, які ми спостерігали в експерименті. В літературі обговорюється зниження когнітивних функцій у щурів при експериментальній помірній гіпоксичній гіпоксії [11] і погіршення оксигенації кори великих півкуль після блокування бета-адренорецепторів за умов значного розведення крові в експерименті [12].

Висновки. У дорослих тварин після перебування в гіпоксичному середовищі нами виявлене посилення парасимпатичних енергозберігаючих

\section{ЛІТЕРАТУРА}

1. Волкова Н. М. Метеотропні зміни регіонарного кровообігу головного мозку і їх адаптивне значення / Н. М. Волкова // Здобутки клінічної і експериментальної медицини. - 2008. - № 2. - С. 32-35.

2. Волкова Н. М. Психологічний статус працездатних осіб у періоді пізньої дорослості за несприятливих метеоумов / Н. М. Волкова // Вестник физиотерапии и курортологии. - 2009. - Т. 15, № 1. - С. 14-17.

3. Bystolic Prescribing Information [Електронний peсурс] // Forest Pharmaceuticals. - 2007. - 14 р. - Режим доступу до журн. : www.fda.gov/medwatch.

4. Ошевенский Л. В. Особенности регуляции вегетативного тонуса у крыс по данным кардиоинтервалографии / Л. В. Ошевенский, Е. П. Лобкаева // Механизмы функционирования висцеральных систем : III Bсероссийская конференция с международным участием, посвященная 175-летию со дня рождения Ф. В. Овсянникова, 29 сентября - 1 октября 2003 г. : тез. докл. Санкт-Петербург, 2003. - С. 238-239. механізмів. В експерименті виключення бета, адренорецепторів в асоціативній корі дорослих щурів за умов зниженого атмосферного тиску виявило залучення бета-адренергічних структур досліджуваного лівого асоціативного кіркового поля до нейронних ланцюгів, які створювали парасимпатичний вплив на серцевий ритм, що відрізнялося від ефекту небівололу при нормальному атмосферному тиску.

Перспективи подальших досліджень. Доцільно вивчити функціональну асиметрію бета адренорецепторів асоціативних ділянок кори великих півкуль за умов поєднаного впливу адаптогенних речовин і зниженого атмосферного тиску.

5. Покровский В. М. Иерархическая система формирования ритма сердца в целостном организме / В. М. Покровский // Механизмы функционирования висцеральных систем : III Всероссийская конференция с международным участием, посвященная 175-летию со дня рождения Ф. В. Овсянникова, 29 сентября 1 октября 2003 г. : тез. докл. - Санкт-Петербург, 2003. C. 256-257.

6. Mason R. P. Evolving mechanisms of action of beta blockers: focus on nebivolol / R. P. Mason, T. D. Giles, J. R. Sowers // J. Cardiovasc. Pharmacol. - 2009. - Vol. 54, № 2. - P. 123-128.

7. Münzel T. Nebivolol: the somewhat-different beta-adrenergic receptor blocker / T. Münzel, T. Gori // J. Am. Coll. Cardiol. - 2009. - Vol. 54, № 16. - P. 1491-1499.

8. Nebivolol: haemodynamic effects and clinical significance of combined beta-blockade and nitric oxide release / O. Kamp, M. Metra, S. Bugatti [et al.] // Drugs. 2010. - Vol. 70, № 1. - P. 41-56. 
Огляди літератури, оригінальні дослідження, погляд на проблему

9. Регуляторная роль митохондриальной дисфункции при гипоксии и ее взаимодействие с транскрипционной активностью / Л. Д. Лукьянова, А. М. Дудченко, Т. А. Цыбина, Э. Л. Германова // Вестник Российской AMH. - 2007. - № 2. - С. 3-13.

10. Волкова Н. М. Ефективність автономної регуляції кровообігу у метеочутливих осіб / Н. М. Волкова // Здобутки клінічної і експериментальної медицини. 2012. - № 1. - С. 23-28.

11. Physostigmine reverses cognitive dysfunction caused by moderate hypoxia in adult mice / A. Bekker, M. Haile, K. Gingrich [et al.] // Anesth. Analg. - 2007. Vol. 105, № 3. - P. 739-743.

12. b2 Adrenergic antagonist inhibits cerebral cortical oxygen delivery after severe haemodilution in rats / G. M. T. Hare, J. M. A. Worrall, A. J. Baker, E. Liu, N. Sikich, C. D. Mazer // Br. J. Anaesth. - 2006. - Vol. 97. - P. 617-623.

\title{
THE IMPACT OF EXCLUSION BETA 1-ADRENERGIC RECEPTORS ASSOCIATIVE CORTEX OF ADULT RATS ON AUTONOMIC REGULATION OF THE HEART RHYTHM IN CONDITIONS OF LOW ATMOSPHERIC PRESSURE
}

@N. M. Volkova

\author{
SHEI «Ternopil State Medical University by I. Ya. Horbachevsky of MPH of Ukraine»
}

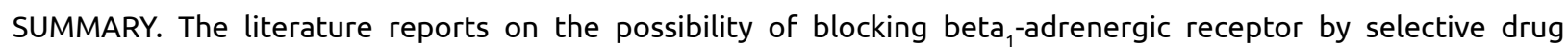
nebivolol. But there is no data on the effects of blocking beta1-adrenergic receptors in the associative cortical fields to autonomous regulation of heart rate. However, there is a possibility for modeling hypobaric and hypoxic conditions in the experiment. The aim of the experiment was to determine the functional consequences of blocking beta-adrenergic receptors in the associative cortex of adult rats under low atmospheric pressure. In the experiment, the blocking of beta ${ }_{1}-$ adrenergic receptors in the associative cortex of adult rats under low atmospheric pressure revealed the involvement of beta ${ }_{1}$-adrenergic structures in left associative cortical field to the neural circuits that provide parasympathetic influence on the heart rate. This effect was different from the result of nebivolol action at analoges experiment under the normal atmospheric pressure.

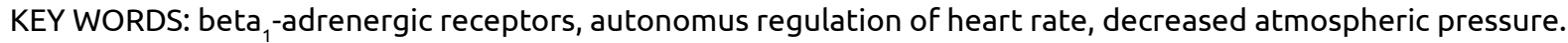

Отримано 15.10.2015 